\title{
ANALISIS PENGARUH GAYA KEPEMIMPINAN TRANSFORMASIONAL DAN LINGKUNGAN KERJA NON FISIK TERHADAP KEPUASAN KERJA KARYAWAN PADA PT. PELABUHAN INDONESIA 1 ( PERSERO ) CABANG BELAWAN
}

\author{
Mawar Ningsih \\ Alumni Jurusan Manajemen Fakultas Ekonomi Universitas Negeri Medan \\ Fauzia Agustini \\ Dosen Jurusan Manajemen Fakultas Ekonomi Universitas Negeri Medan
}

\begin{abstract}
This study aims to identify and explain the Influence Influence Transformational Leadership Style and Non-Physical Work Environment The Job Satisfaction simultaneously and partially at PT Pelabuhan Indonesia I (Persero) Branch Belawan.

This research was conducted at the office of PT Pelabuhan Indonesia I (Persero) Branch Belawan in the academic year 2014, with a population of 255 employees and a sample totaling 72 employees. Data collection techniques used were observation, and questionnaires. Reliability of the questionnaire using Cronbach Alpha test, and validity tested questionnaire with product moment correlation test. In this study, whole grains valid questionnaires. After the data were analyzed with SPSS 16, the obtained path analysis $Y=0.354+0.600 x \_1 \quad x \_2+0.125$. to determine the effect of independent variables on the dependent variable is the coefficient of determination with simultaneous use $87.5 \%$ with significant results using the $F$ test. These results indicate that the influence of Transformational Leadership Style and Non-Physical Work Environment The Job Satisfaction of employees simultaneously at PT Pelabuhan Indonesia I (Persero) Branch Belawan of $87.5 \%$. Effect of Transformational Leadership Style partially on employee job satisfaction was $12.5 \%$ significantly by using T test. Effect of Non-Physical Work Environment partially on employee job satisfaction significantly by $36.0 \%$ by using the test T. Thus the hypothesis of this study is accepted that there Pengeruh between Transformational Leadership Style and Non-Physical Work Environment Against Employee Satisfaction At PT Pelabuhan Indonesia I (Persero) Branch Belawan.
\end{abstract}

Keywords: Transformational Leadership Style, Non-Physical Work Environment, Job Satisfaction.

\section{PENDAHULUAN}

Salah satu cara bagi perusahaan agar tetap survive dalam era globalisasi adalah memiliki sumber daya manusia yang berkualitas dan bersemangat kerja tinggi dalam mengerjakan semua tugas dan kewajibannya terhadap perusahaan sehingga tujuan perusahaan dapat tercapai dengan baik. Karyawan yang efektif dibutuhkan dalam menghadapi kompetisi pasar global yang semakin ketat. Karyawan dapat bekerja secara efektif bila dilandasi oleh kepuasan kerja dan semangat kerja.

Menurut Hasibuan (2011:202) "Kepuasan kerja adalah sikap emosional yang menyenangkan dan mencintai pekerjaannya". Seseorang dengan tingkat kepuasan kerja yang tinggi mempunyai sikap positif terhadap pekerjaannya, dan cenderung lebih produktif. Dengan demikian akan membuat karyawan 
bekerja lebih baik yang pada akhirnya akan meningkatkan produktivitasnya.

Adanya rasa ketidakpuasan yang dirasakan sejumlah karyawan pada perusahaan biasanya terjadi akibat adanya kesenjangan yang dirasakan antara apa yang diinginkan oleh karyawan dengan apa yang diberikan perusahaan kepadanya. Apabila kesenjangan itu semakin tinggi, maka ketidakpusan karyawan akan meningkat. Ketidakpuasaan ini akan menyebabkan semangat kerja, motivasi serta gairah dalam menjalankan pekerjaan akan menurun.

Sehubungan dengan sikap karyawan terhadap pekerjaannya, maka adapun faktor-faktor yang terkait dengan kepuasan kerja salah satunya adalah gaya kepemimpinan. Suhendra (dalam Sujana dan Dewi, 2012:1295), "Kepemimpinan menggambarkan hubungan antara pemimpin (leader) dengan yang dipimpin (follower) dan bagaimana seorang pemimpin mengarahkan follower untuk menentukan sejauh mana follower mencapai tujuan atau harapan pimpinan".

Selain gaya kepemimpiann, faktor lain yang juga sangat mempengaruhi kepuasan kerja karyawan adalah lingkungan kerja. Hal ini sesuai dengan pendapat Hasibuan (2005:203) yang menyatakan ada beberapa faktor yang mempengaruhi kepuasaan kerja, salah satu diantaranya adalah suasana dan lingkungan pekerjaan. Apabila lingkungan kerja baik, aman, nyaman dan memenuhi standart maka akan menciptakan kepuasan kerja bagi karyawan sehingga memberikan kenyamanan bagi karyawan dalam melaksanakan pekerjaannya dan akan berdampak baik bagi produktivitas dalam perusahaan.

Menurut Sedarmayanti (dalam Khoiriyah, 2009), lingkungan kerja terbagi 2 (dua), yaitu lingkungan kerja fisik dan Lingkungan kerja non fisik. Lingkungan kerja fisik meliputi penerangan, warna, cahaya, suhu, uda dan suara. Sedangkan lingkungan kerja non fisik, meliputi pengawasan, suasana kerja dan hubungan kerja.

PT. Pelabuhan Indonesia 1 (Persero) Cabang Belawan adalah sebuah Badan Usaha Milik Negara yang bergerak dalam pelayanan jasa kepelabuhan, pelayanan kapal, pelayanan barang, dan pelayanan terminal peti kemas. Sesuai dengan pengamatan dan hasil wawancara penulis dengan salah satu staf bagian MSDM dan bagian Umum, gaya kepemimpinan yang ada pada PT. Pelabuhan Indonesia 1 (Persero) Cabang Belawan ini adalah gaya kepemimpinan transformasinal. Hasil wawancara yang telah penulis lakukan dengan beberapa karyawan, juga menunjukkan bahwa hubungan antar karyawan masih belum terjalin dengan baik. Hal ini dikarenakan intensitas pertemuan yang masih kurang, karena jarak antara divisi yang satu dengan divisi lainnya agak jauh.

\section{KAJIAN PUSTAKA}

Kepemimpinan Transformasional

Pengertian Kepemimpinan

Transformasional

Bass dalam (Mamesah dan

Kusmaningtyas, 2009 : 353),

mengemukakan bahwa

"kepemimpinan transformasional

berkenaan dengan pengaruh

pemimpin atau atasan terhadap

bawahan. Para bawahanmerasakan 
adanya kepercayaan, kebanggaan, loyalitas dan rasa hormat kepada atasan danmereka termotivasi untuk melakukan melebihi apa yang diharapkan".

Sunarsih (dalam Suastika dan Putra 2012:19) mendefinisikan kepemimpinan transformasional sebagai "model kepemimpinan dimana pemimpin mempunyai kekuatan untuk mempengaruhi bawahan dengan cara-cara tertentu, bawahan merasa percaya, kagum, loyal dan hormat terhadap atasannya sehingga bawahan termotivasi untuk berbuat lebih banyak dari pada apa yang biasa dilakukan dan diharapkannya".

Menurut Robbin (dalam Utami, 2012:76) "Kepemimpinan transformasional yaitu pemimpin yang mencurahkan perhatiannya kepada persoalan yang dihadapi oleh para pengikutnya dan kebutuhan pengembangan dari masing-masing pengikutnya dengan cara memberikan semangat dan dorongan untuk mencapai tujuannya".

\section{Ciri-Ciri}

\section{Transformasional}

Menurut Dubinsky (dalam Mamesah dan Kusmaningtyas, 2009:354) beberapa karakteristik personal yang mendukung keberhasilan kepemimpinan trasnformasional adalah:

1. Emotional coping.

Merupakan derajat seorang individu yang mempunyai kecenderungan tidak sensitif terhadap celaan orang lain dan tidak kuatir secara berlebihan terhadap suatu kegagalan.

2. Behavioral coping.
Berkenaan dengan karakteristik individu yang berpikir dan berperilaku secara efektif.

3. Abstract orientation.

Individu mampu menilai dan mengevaluasi ide-ide yangkritis.

4. Risk taking.

Individu memiliki kemauan untuk berubah dan tenang menghadapikesulitan sehingga mereka lebih persuasif, memiliki pengaruh yang kuat dan efektif.

5. Inovation.

Pemimpin transformasional selalu ingin mencoba sesuatu yang baru danberbeda serta lebih kreatif.

6. Use of humor.

Pemimpin menggunakan humor untukmengembangkan hubungan yang menyenangkan dan menghilangkan situasi tegang.

7. Experience.

Pengalaman akan memberikan kesempatan pada individu untukmengidentifikasikan dan memilih suatu pendekatan kepemimpinan yang cocok danmeningkatkan efektifitas kepemimpinan.

Menurut Robbin (dalam Utami, 2012:4), indikator dari gaya kepemimpinan transformasional yaitu

1. Visi dan misi, menanamkan kebanggaan, meraih penghormatan dan kepercayaan.

2. Mengkomunikasikan harapan tinggi, menggunakan symbol untuk memfokuskan pada usaha, menggambarkan maksud penting secara sederhana.

3. Mendorong intelegensi, rasionalitas dan pemecahan masalah secara hati-hati. 
4. Memberikan perhatian pribadi, melayani secara pribadi, melatih dan menasehati.

\section{Lingkungan Kerja Non Fisik Pengertian Lingkungan Kerja Non \\ Fisik}

Sedarmayanti (dalam Sukamto dkk, 2013:5) mengatakan, “ Lingkungan kerja non fisik adalah semua keadaan yang terjadi yang berkaitan dengan hubungan kerja, baik hubungan dengan atasan maupun hubungan sesama rekan kerja, ataupun hubungan dengan bawahan".

Sedangkan, Wursanto (dalam Dharmawan, 2011:59) menyebutnya sebagai "lingkungan kerja psikisyang didefinisikan sebagai sesuatu yang menyangkut segi psikisdari lingkungan kerja. Segi psikis menyangkut keadaan di tempat kerja yang berkaitan dengan hubungan antar personal".

\section{Faktor-Faktor}

yang

Mempengaruhi Lingkungan Kerja Non Fisik

Menurut Soehardi (2003:183), faktor-faktor yang mempengaruhi lingkungan kerja non fisik adalah sebagai berikut :

a. Lingkungan Sosial

Lingkungan sosial yang berpengaruh terhadap karyawan adalah latar belakang karyawan. Misalnya pada perusahaan jsa, faktor psikologis yang berupa beban sosial sangat berpengaruh terhadap kepuasan kerjanya dan masuk dalam pertimbangan perencanan lingkungan kerja.

b. Status Sosial

Faktor status sosial yang dimaksud adalah jabatan seorang karyawan dalam sebuah perusahaan. Semakin tinggi jabatan pekerja semakin besar pula kewenangan dan keleluasaan untuk mengambil keputusan. Tingkat jabatan antar pekerja di suatu lingkungan kerja sangat perlu dipertimbangkan oleh perusahaan untuk menciptakan kepuasan kerja karyawan.

c. Hubungan kerja dalam kantor Merupakan hubungan kerja yang terjalin baik antar pekerja, ataupun antara pekerja dengan pemimpin perusahaan.

d. Sistem Informasi

Komunikasi yang dimaksud adalah alat yang digunakan untuk menyampaikan ide, saran, pesan, perintah, ataupun berita dari seseorang kepada orang lain, agar diantara mereka terdapat interaksi. Karena komunikassi yang baik akan mempermudah karyawan dalam memperoleh informasi yang dibutuhkan.

e. Kesempatan

Pemberian kesempatan dan peluang untuk berkembang, mempunyai dampak positif terhadap kepuasan kerja para karyawan. Untuk menciptakan lingkungan kerja yang kondusif , harus diciptakan kondisi 1;ingkungan yang dapat mendorong karyawan dan member kesempatan untuk lebih berinovatif.

Indikator Lingkungan Kerja Non Fisik

Indikator Lingkungan Kerja Non Fisik yang digunakan dalam penelitian ini adalah berdasar pada indikator yang telah diuraikan di atas, yaitu :

1. Hubungan karyawan 
2. Keamanan kerja

3. Suasana kerja

4. System imbalan

5. Perlakuan yang baik

\section{Kepuasan Kerja \\ Pengertian Kepuasan Kerja}

Menurut Martoyo (2011:21), "kepuasan kerja adalah keadaan emosional dimana terjadi ataupun tidak terjadi antara nilai balas jasa karyawan dari perusahaan". Sedangkan menurut Handoko (dalam Sinaga,2013:21) menyatakan bahwa "kepuasan kerja adalah keadaan emosional yang menyenangkan dengan mana pera karyawan memandang pekerjaan mereka".

Menurut Martoyo (2011:21), "kepuasan kerja adalah keadaan emosional dimana terjadi ataupun tidak terjadi antara nilai balas jasa karyawan dari perusahaan" sedangkan Handoko (dalam Sinaga, 2013:21) menyatakan, "kepuasan kerja adalah keadaan yang menyenangkan dengan para karyawan memandang pekerjaan mereka”. Robbins (2008:40), "kepuasan kerja adalah suatu perasaan positif tentang pekerjaan seseorang yang merupakan hasil dari evaluasi karakteristiknya".

\section{Faktor-faktor yang Mempengaruhi Kepuasan Kerja}

Blum dan Edy (dalam Sinaga, 2013:31) mengatakan faktor-faktor yang mempengaruhi kepuasan kerja, adalah :

1. Faktor individual, meliputi umur, watak dan harapan.

2. Faktor sosial, meliputi hubungan kekeluargaan, pandangan pekerjaan, kebebasan berpolitik dan hubungan kemasyarakatan.
3. Faktor utama dalam pekerjaan, meliputi upah, pengawasan, ketentraman penghargaan terhadap kecakapan untuk maju. Selain itu juga penghargaan terhadap kecakapan dalam menyelesaikan konflik antar manusia, perasaan diperlakukan adil baik yang menyangkut pribadi maupun tugas.

\section{Indikator-Indikator Kepuasan Kerja}

Menurut Job Descriptive Index

(JDI) (dalam Sinaga, 2013:33) indikator kepuasan kerja adalah :

1. Pay (penggajian), yaitu suatu balas jasa yang diterima karyawan dalam bentuk finansial atas pekerjaan yang telah mereka lakukan. Karyawan akan merasa puas jika imbalan/gaji yang diperoleh sesuai dengan tuntutan pekerjaannya.

2. Promotion (promosi), yaitu peluang untuk mengalami peningkatan dalam hierarki, kesempatan promosi memiliki pengaruh terhadap kepuasan kerja, ini dikarenakan promosi merupakan kesempatan untuk mengembangkan diri dengan tingkat karir yang lebih tinggi dan imbalan yang lebih besar.

3. Supervisory (pengawasan), yaitu hal yang cukup mempengaruhi dari kepuasan kerja. Kemampuan dari supervisor untuk melakukan pengawasan yang tepat dan untuk menyediakan bantuan teknik dan dukungan. Hal tersebut dapat berupa dari adanya pengawasan langsung yang dilakukan oleh seorang atasan terhadap bawahannya. 
4. Work (pekerjaan itu sendiri), karyawan akan lebih tertarik pada pekerjaan yang menyediakan tugas-tugas yang menarik bagi karyawan itu sendiri dan karyawan akan lebih menyukai pekerjaan-pekerjaan yang memberikan kesempatan bagi karyawan untuk menggunakan pengetahuannya dalam pekerjaannya. Hal ini akan menjadi sumber utama dalam kepuasan kerja.

5. Co-Workers (rekan kerja), hubungan antar rekan kerja berpengaruh terhadap kepuasan seorang karyawan. Karyawan akan merasa betah dan tidak merasa bosan jika rekan kerja di tempat bekerja menyenangkan dan saling peduli satu sama lain. Hal ini akan memberikan kepuasan tersendiri bagi karyawan tersebut.

\section{METODE PENELITIAN}

Penelitian ini dilakukan di Kantor PT. Pelabuhan Indonesia I (Persero) Cabang Belawan, Jln. Kapten R. Sulian No.1 Belawan. Sampel yang diambil dalam penelitian adalah seluruh karyawan Kantor PT. Pelabuhan Indonesia I (Persero) Cabang Belawan, yang keseluruhannya berjumlah 72 orang. Metode pengambilan sampel menggunakan random sampling
(Proportionate Stratified Random Sampling).

Sedangkan variabel dalam

penelitian ini adalah :

a. Variabel Bebas $\left(\mathrm{X}_{1}\right)$ :

Kepemimpinan Transformasional

b. Variabel Bebas $\left(\mathrm{X}_{2}\right)$ : Lingkungan

Kerja Non Fisik

c.Variabel Terikat (Y) : Kepuasan

Kerja

Model analisis yang digunakan dalam penelitian ini adalah analisis jalur. Analisis jalur digunakan untuk menganalisis pola hubungan antar variabel dengan tujuan untuk mengetahui pengaruh langsung maupun tidak langsung seperangkat variabel bebas (eksogen) terhadap variabel intervening atau variabel perantara" (Riduwan dan Kuncoro, 2007:2). Kerangka hubungan antara jalur $\left(\mathrm{X}_{1}, \mathrm{X}_{2}\right.$, dan $\left.\mathrm{Y}\right)$ dapat dibuat melalui persamaan variabel sebagai berikut :

$$
Y-p y X_{1}+p y X_{2}+p y s 1
$$

\section{HASIL PENELITIAN DAN PEMBAHASAN}

Dari hasil SPSS diketahui masing-masing koefisien jalur dari setiap variabel, dan didapatkan persamaan sebagai berikut :

$$
Y=0,354 X_{1}+0,600 X_{2}+0,125 e
$$

Besarnya pengaruh variabel secara proporsional dapat dijelaskan sebagai berikut :

a. Pengaruh Gaya Kepemimpinan Transformasional $\left(X_{1}\right)$ terhadap Kepuasan

Kerja (Y)

Pengaruh Langsung $\quad=\mathrm{P}_{\mathrm{y}} \mathrm{X}_{1}^{2}$

$$
\begin{aligned}
& =0,354^{2} \\
& =0,125
\end{aligned}
$$

Pengaruh Tidak Langsung $\mathrm{X}_{1}$ melalui $\mathrm{X}_{2}$

$$
\begin{aligned}
& ={ }_{\text {py }} \mathrm{X}_{1 . \mathrm{r}} \mathrm{X}_{1} \mathrm{X}_{2 \cdot} \cdot{ }_{\mathrm{Py}} \mathrm{X}_{2} \\
& =0,354 \cdot 0,925 \cdot 0 \cdot 600
\end{aligned}
$$


JURNAL PLANS

Penelitian Ilmu Manajemen \& Bisnis

ISSN: $1978-7057$

E-ISSN: 2527-306X

$$
=0,196
$$

b. Pengaruh Lingkungan Kerja Non Fisik $\left(X_{2}\right)$ terhadap Kepuasan Kerja Karyawan.

Pengaruh Langsung $\quad={ }_{\mathrm{Py}} \mathrm{X}_{2}{ }^{2}$

$$
=0,600^{2}
$$

$$
=0,360
$$

Pengaruh Tidak Langsung $\mathrm{X}_{1}$ melalui $\mathrm{X}_{2}$

$$
\begin{aligned}
& ={ }_{P y} X_{2 \cdot r} X_{1} X_{2 \cdot p y} X_{1} \\
& =0,600 \cdot 0,925 \cdot 0,354 \\
& =0,96
\end{aligned}
$$

c. Pengaruh Simultan Gaya Kepemimpinan Transformasional $\left(X_{1}\right)$, Lingkungan Kerja Non Fisik $\left(X_{2}\right)$ terhadap Kepuasan Kerja.

$$
\begin{aligned}
\mathrm{r}^{2} \mathrm{Y}\left(X_{1} \cdot X_{2}\right) \quad & =\left|p y X_{1} p y X_{2}\right|\left|\begin{array}{c}
r_{y} X_{1} \\
r_{y} X_{2}
\end{array}\right| \\
& =|0,354.0,600|\left|\begin{array}{c}
0,910 \\
0,928
\end{array}\right| \\
& =0,162+0,713 \\
& =0,875 \text { (angka tersebut adalah koefisien determinasi) }
\end{aligned}
$$

Keterangan :

1. Pengaruh Gaya Kepemimpinan $\left(X_{1}\right)$ terhadap Kepuasan Kerja (Y) sebesar 0,125 atau $12,5 \%$

2. Pengaruh Lingkungan Kerja Non Fisik $\left(X_{2}\right)$ terhadap Kinerja (Y) sebesar 0,360 atau $36,0 \%$

3. Pengaruh Gaya Kepemimpinan $\left(X_{1}\right)$ dan Lingkungan Kerja Non Fisik $\left(X_{2}\right)$ secara bersamaan terhadap Kepuasan Kerja (Y) sebesar 0,875 atau $87,5 \%$. Sisanya yaitu sebesar 0,125 atau $12.5 \%$ dipengaruhi oleh faktor - faktor lain yang tidak dapat dijeaskan dalam penelitian ini.

Dari perhitungan menggunakan program SPSS (tabel 2) dapat disimpulkan bagaimana hubungan masing-masing variabel independen terhadap variabel dependen (uji t) :
1. Gaya
Kepemimpinan

Transformasional $\left(X_{1}\right)$ terhadap

Kepuasan Kerja (Y)

Variabel $\mathrm{X}_{1}$ mempunyai $t_{\text {hitung }}$ yakni 3,209 dengan $t_{\text {tabel }}=1,667$.
Jadi $t_{\text {hitung }}>t_{\text {tabel }}$ dapat disimpulkan bahwa variabel $\mathrm{X}_{1}$ memiliki kontribusi terhadap Y. Nilai $\mathrm{t}$ positif menunjukkan bahwa variabel $\mathrm{X}_{1}$ mempunyai hubungan yang searah dengan $\mathrm{Y}$. Jadi dapat disimpulkan Gaya Kepemimpinan Transformasional $\left(X_{1}\right)$ memiliki pengaruh signifikan terhadap kepuasan kerja (Y), maka $\mathrm{H}_{1}$ diterima. Nilai signifikansi perhitungan adalah $0.002<0.05$ yang berarti bahwa pengaruh bersifat langsung dan secara signifikan mempengaruhi variable dependen.

2. Lingkungan Kerja non Fisik $\left(X_{2}\right)$ terhadap Kepuasan Kerja (Y)

Variabel $\mathrm{X}_{2}$ mempunyai $\mathrm{t}_{\text {hitung }}$ yakni 5,432 dengan $t_{\text {tabel }}=1,667$. Jadi $t_{\text {hitung }}>t_{\text {tabel }}$ dapat disimpulkan bahwa variabel $\mathrm{X}_{2}$ memiliki kontribusi terhadap $\mathrm{Y}$. Nilai $\mathrm{t}$ positif menunjukkan bahwa $\mathrm{X}_{2}$ mempunyai hubungan yang searah dengan Y. Jadi dapat disimpulkan 
Lingkungan Kerja non Fisik $\left(X_{2}\right)$ memiliki pengaruh signifikan terhadap Kepuasan Kerja (Y) maka $\mathrm{H}_{2}$ diterima. Nilai signifikansi perhitungan adalah $0.000<0.05$ yang berarti bahwa pengaruh bersifat langsung dan secara signifikan mempengaruhi variable dependen.

Sehingga ringkasan hasil pengujian hipotesis setelah dilakukan uji statistik atas data adalah sbb:

1. $\mathrm{H}_{1}$ diterima yaitu Gaya

Kepemimpinan

Transformasional

berpengaruh Kepuasan Kerja (Y)

2. $\mathrm{H}_{2}$ diterima yaitu Lingkungan Kerja non Fisik $\left(X_{2}\right)$ berpengaruh terhadap kepuasan kerja (Y)

Pengaruh dari kedua variabel bebas secara serentak terhadap variabel terikat dapat dilihat dari hasil uji $\mathrm{F}$. adapun syarat dari uji $\mathrm{F}$ adalah jika $F_{\text {hitung }}>F_{\text {tabel }}$ maka Ho ditolak dan $\mathrm{H} 1$ diterima.

Dari hasil SPSS diperoleh nilai $F_{\text {Hitung }}$ sebesar 250,520 dengan nilai probabilitas $(\mathrm{sig})=0,000$. Nilai $\mathrm{F}_{\text {Hitung }}$ $(250,520)>\mathrm{F}_{\text {Tabel }}(3,13)$ dan nilai sig lebih kecil dari nilai probabilitas 0,05 atau nilai $0,000<0,05$; maka $\mathrm{H}_{3}$ diterima, yaitu gaya kepemimpinan transformasional dan lingkungan kerja non fisik secara bersama sama (simultan) berpengaruh signifikan terhadap kepuasan kerja karyawan.

Untuk mengetahui seberapa besar persentase pengaruh variabel bebas terhadap variabel terikat atau untuk melihat seberapa besar variabel bebas dapat menjelaskan pengaruhnya terhadap variabel terikat. Maka dilakukan pengujian koefisien determinasi $\left(\mathrm{R}^{2}\right)$ sehingga diperoleh hasil seperti tabel di bawah ini.

Secara keseluruhan variabelvariabel bebas secara bersama sama mempengaruhi variabel terikat. Keseluruhan variabel mempengaruhi secara positif dan signifikan dengan persamaan regresi adalah : $\mathrm{Y}=1,657$ $+0,366 X_{1}+0,759 X_{2}+$ e. Dari persamaan regresi tersebut, didapat koefisien determinasi adalah sebesar 87,55 (Adjusted $\mathrm{R}^{2} \times 100 \%$ ) yang berarti gaya kepemimpinan transformasional $\left(\mathrm{X}_{1}\right)$ dan lingkungan kerja non fisik $\left(\mathrm{X}_{2}\right)$ berpengaruh signifikan terhadap kepuasan kerja (Y) sebesar $87,5 \%$ dengan 12,55 lainnya dipengaruhi oleh faktor lain diluar variabel yang diteliti.

\section{PENUTUP}

Berdasarkan hasil penelitian yang diperoleh, maka dapat dibuat beberapa kesimpulan, yaitu :

1. Persamaan structural untuk diagram Jalur pada penelitian ini yaitu :

$\boldsymbol{Y}=0,354 X_{1}+0,600 X_{2}+0,125 e$

Dimana, makna atau penjelasan Persamaan structural untuk diagram Jalur tersebut, yaitu : Jika variabel $\mathrm{X}_{1}$ (gaya kepemimpinan Transformasional) jumlahnya bertambah 1, maka akan mempengaruhi variabel $\mathrm{Y}$ (kepuasan kerja) sebanyak jumlah keseluruhan persamaan diatas. Begitu juga dengan $\mathrm{X}_{2}$ (lingkungan kerja non fisik).

2. Gaya kepemimpinan Transformasional $\left(x_{1}\right)$, terhadap Kepuasan Kerja (Y) Variabel $\mathrm{X}_{1}$ mempunyai $t_{\text {hitung }}$ yakni 3,209 dengan $t_{\text {tabel }}=1,667$. Jadi $t_{\text {hitung }}>t_{\text {tabel }}$ dapat disimpulkan bahwa variabel $\mathrm{X}_{1}$ memiliki 
kontribusi terhadap Y. Jadi dapat disimpulkan Gaya Kepemimpinan Transformasional $\left(X_{1}\right)$ memiliki pengaruh signifikan terhadap kepuasan kerja (Y) maka $\mathrm{H}_{1}$ diterima dan Ho ditolak. Nilai signifikansi perhitungan adalah $0.002<0.05$ yang berarti bahwa pengaruh bersifat positif dan secara signifikan mempengaruhi variable dependen.

3. Lingkungan Kerja non Fisik $\left(X_{2}\right)$ terhadap Kepuasan Kerja (Y) Variabel $\mathrm{X}_{2}$ mempunyai $t_{\text {hitung }}$ yakni 5,432 dengan $t_{\text {tabel }}=1,994$. Jadi $t_{\text {hitung }}>t_{\text {tabel }}$ dapat disimpulkan bahwa variabel $\mathrm{X}_{2}$ memiliki kontribusi terhadap Y. Jadi dapat disimpulkan Lingkungan Kerja non Fisik $\left(X_{2}\right)$ memiliki pengaruh signifikan terhadap Kepuasan Kerja (Y) maka $\mathrm{H}_{1}$ diterima dan Ho ditolak. Nilai signifikansi perhitungan adalah $0.000<0.05$ yang berarti bahwa pengaruh bersifat positif dan secara signifikan mempengaruhi variable dependen.

4. Pengaruh Gaya Kepemimpinan Transformasional dan lingkungan kerja non fisik secara simultan terhadap kepuasan kerja dengan nilai $F_{\text {hitung }}$ sebesar 250,520 dengan nilai probabilitas (sig) $=0,000$. Nilai $F_{\text {hitung }}(250,520)>F_{\text {tabel }}$ $(3,13)$, dan nilai sig. lebih kecil dari nilai probabilitas 0,05 atau nilai $0,000<0,05 ;$ maka $\mathrm{H}_{3}$ diterima, berarti secara bersamasama (simultan) $\left(X_{1}\right)$ dan Lingkungan Kerja non Fisik $\left(X_{2}\right)$ berpengaruh signifikan terhadap Kepuasan Kerja (Y) diterima dan menolak Ha.

\section{DAFTAR PUSTAKA}

Dharmawan, Yusa. 2011. Pengaruh Kompensasi dan Lingkungan Kerja non fisik terhadap Disiplin dan Kinerja Karyawan Hotel Nikki Denpassar.

Hasibuan, Malayu S.P. 2011. Manajemen Sumber Daya Manusia. Jakarta : CV. Haji Masagung

Husein, dkk. 2012. Pengaruh Lingkungan Kerja dan Karakteristik Individu terhadap kepuasan kerja Karyawan Hotel Melati Di Kecamatan Banjarmasin Tengah. Jurnal Manajemen dan Akuntansi. 13 (1) : 35-44.

Kaihatu, dkk. 2007. Kepemimpinan Transformasional dan Pengaruhnya terhadap Kepuasan atas Kualitas Kehidupan kerja, Komitmen organisasi, dan prilaku ekstra peran : study pada Guru-guru di Kota Surabaya. Jurnal Manajemen dan Kewirausahaan. 98. (1) : 4961.

Mamesah, dkk. 2009. Pengaruh Gaya Kepemimpinan

Transformasional dan Transaksional Terhadap kepuasan kerja dan Dampaknya terhadap Kinerja Karyawan. Jurnal Akuntansi, Manajemen bisnis. 5 (3) : 349368.

Martoyo, Susilo. 2011. Manajemen Sumber Daya Manusia. Rineka cipta, Jakarta.

Robbins, Stephens. 2008. Prilaku organisasi (Organizational Behaviour). Jakarta : Salemba Empat. 
JURNAL PLANS

Penelitian Ilmu Manajemen \& Bisnis

ISSN: $1978-7057$

E-ISSN: 2527-306X

Sinaga, Rimdaniyati. 2013. Pengaruh Kepribadian dan Lingkungan kerja Non Fisik terhadap Kepuasan Kerja Karyawan pada PT. PLN (Persero) unit induk pembangunan jaringan sumatera. Medan.

Soehardi.2003.http://docs.google.com /faktor+yang+mempengaruhi +1 ingkungan +

kerja + on+fisik + menurut+Soeh ardi

Suastika, dkk. 2012. Pengaruh Kompensasi, Gaya

Kepemimpinan

Transformasional Komunikasi dan terhadap
Kepuasan Kerja dan Semangat Kerja.

Sukamto, dkk. 2013. Pengaruh Lingkungan Kerja Fisik dan Non Fisik terhadap Kinerja pegawai pada Badan Ketahanan Pangan dan Pelaksana Penyuluhan Daerah Kota Samarinda. Jurnal Administrative Reform. 1 (2) : 431-443.

Utami, Lis torisa. 2012. Pengaruh Gaya Kepemimpinan Transformasional terhadap Motivasi kerja Karyawan pada PT. Trade Servistama Indonesia-Tanggerang. 